\title{
Problems Faced by Women in Male out Migrant Households
}

\author{
Veena Chandawari* and Shobha Nagnur \\ Department of Extension and Communication Management, University of Agricultural \\ Sciences, Dharwad 580 005, Karnataka, India \\ *Corresponding author
}

\section{Keywords \\ Problems, Women, Male out, Migrant \\ Article Info \\ Accepted: \\ 10 October 2019 \\ Available Online: \\ 10 November 2019}

\section{A B S T R A C T}

Male out-migration is the most often adopted strategy in rural areas to surmount risks associated with agriculture and to diversify income. There are various reasons for the increased exodus of labor from rural areas, such as underdevelopment, unemployment, less availability of non-farm jobs and population pressure. Male persistent absence has many repercussions on women left behind. Migration can bring financial prosperity but it causes the absences of traditional cultural figure from family, which ultimately brings a changes in the lives of left behinds, the wives and children. After male migration, female members are expected to perform all the functions what the male person was taking care off. This over burden of responsibilities makes them to become more stressful. They also feel emotionally insecure because of physical separation from the husband. Hence, an attempt is made to analyze the problems faced by women in male out- migration families. The study was carried out in Bagalkot, Vijayapura, Dharwad, Gadag and Haveri districts of North Karnataka. A purposive random sampling technique was followed to select the blocks and villages with the sample size of 200 respondents. Wives of the migrants acted as the respondents who were interviewed personally and the data was collected using pre-tested, structured interview schedule. In the present study their problems are categorised as sociopersonal, economic, psychological, reproductive health and agricultural problems. The findings revealed that major problems in male out migration families, cent per cent of the women said that work burden has increased and their husbands do not send them money on terms (irregular remittance), 87 per cent of them felt loneliness, 73.50 per cent of them faced eve teasing, 68 per cent of the woman felt insecure due to absence of their husbands, 45.50 per cent of the women were not able to visit gynecologists in the absence of their husbands and 95.87 per cent of the women did not have lands in their own names and so could not avail loans and other government facilities. The central and state government should create more livelihood opportunities for the people within rural area, by implementing suitable schemes to control the increasing trend of migration. 


\section{Introduction}

Although the country has achieved success in many fields like science and technology, literature etc. there are some issues plaguing the country and more prominently in the rural areas. Six lakh villages in the country are the soul of our country where maximum of its population resides. Yet it is also the most neglected in terms of civic amenities, infrastructure, development and general wellbeing of the population. The major victims of the issues present in the rural areas are its women and they are facing many problems. Their contribution in agriculture is well known and in spite of her work on the farms her role is considered to be that of care takers and child rears. Due to gender discrimination, women are kept confined to their households and not allowed to participate in many developmental and social activities. With this background, when male migrates to urban cities the problems of women increase multifold. In the present study their problems are categorised as socio-personal, economic, psychological, reproductive health and agricultural problems.

\section{Materials and Methods}

The study was carried out in Bagalkot, Vijayapura, Dharwad, Gadag and Haveri districts of North Karnataka. The purposive random sampling technique was followed to select the blocks and villages. The districts with high migration were selected purposively. Ten talukas were randomly selected from each of the 5 districts.

Further 2 villages from each taluka were selected. The total number of villages was 20 . From each of the village 10 women respondents whose husbands had migrated were selected, making a total sample of 200 women. The data was tabulated and analysed using frequency \& percentage.

\section{Results and Discussion}

\section{Problems faced by women in the absence of men}

Data presented in 1 revealed the problems faced by women in the absence of men. These problems are categorized as socio personal problems, economic problems, psychological problems, reproductive health problems \& agricultural problems

Among the socio - personal problems, cent per cent of the women said that work burden has increased, 93.50 per cent of them were finding it difficult to taking decision in household makers, 73.50 per cent felt insecure, 61.50 per cent of the women exposed lack of confidence in themselves. Half of the respondents said that they were not able to maintain social relations due to the absence of husband and 39.00 per cent of the women are not able to visit their parents' house / relatives due to shortage of time as they had to bear the responsibility of running the house all alone.

Data presented in table 1 also shows the economic problems faced by women. It was clear from the table that all the woman expressed that their husbands do not send them money on terms (irregular remittance), 92.00 per cent of them were harassed by local money lenders for not repaying in time, 89.00 per cent of the women said that they get less wages than men, 78.00 per cent of the women faced difficulty in availing loans, 77.00 per cent of the women were fining it difficulty to run household affairs with the amount of money sent by their husband and 51.00 per cent of the women said that other family members are not helpful when in need of financial help.

After the migration of men women faced psychological problem i.e., 87 per cent of 
them felt loneliness, 73.50 per cent of them faced eve teasing, 68 per cent of the woman felt insecure due to absence of their husbands, 62.00 per cent of the women had feared social security, domestic violence \& abusive behavior. About 62.00 per cent women had disturbed sleep, 60.00 per cent became emotionally stressed and 54.50 per cent of the women heisted to attend social functions in the absence of the husband. Women also faced some problems related to reproductive health (Table 1). It could be observed from the table that, 45.50 per cent of the women were not able to visit gynecologists in the absence of their husbands, 30.50 per cent of them had delayed conception and 5.50 per cent of the woman expressed lack of sexual satisfaction

Among the migrants studies there were 97 families owning land. Due to migration of men from these household it has become the responsibility of women to look after the agricultural land. The agriculture related problem faced by women is also presented.

It was clear from the table that, 95.87 per cent of the women did not have lands in their own names and so could not avail loans and other government facilities, 83.50 per cent of the women were unable to take decisions during droughts and natural calamities, 89.69 per cent of them has expressed that there are no female extension workers and it is difficult to contact male extension worker, 76.28 of them were not in a position to visit nearby cities to get agricultural inputs, 67.01 per cent of the women had less or no knowledge about seed selection and other inputs requirements and 37.11 per cent of the women said that they were unable to identify pest \& diseases in the crop.

\section{Socio-personal problems}

Socio-personal problems are usually individual problems. Cent per cent of the respondents that work burden increased after husband's migration, 93.50 per cent said they found difficulty in taking decisions about household matters, followed by lack of social security $(73.50 \%)$ and lack of confidence $(61.50 \%)$. Half of the respondents mentioned that they are not able to maintain social relations due to the absence of husband and 39.00 per cent of them expressed that they were unable to visit parents' house or relatives due to lack of time.

These problems are mostly due to the male dominated decision making culture in the rural area's hence women are always dependent on men for all the major decisions of the family, so women face difficulty in making own decisions independently. Lack of confidents streams from lack of exposure to the society and lower level of education.

\section{Economic problems}

Migration is primarily for economic reasons. Basic factors for migration in rural are low agricultural income, agricultural unemployment and under employment. In the absence of men, women face problems in accessing and controlling financial issues. Women have less access to bank and other financial institutions mainly because they do not own lands or have property in their names.

They also face difficulty in following the rules and procedure of such institutions, so they therefore depend on the local money lenders, from whom they borrow at high rates of interest and get into debt traps. Most women don't even have bank accounts in their names. Hence migrant's wives faced problems of irregular remittance $(100.00 \%)$ by men, harassment by local money lenders $(92.00 \%)$, lower wage rates than men $(89.00 \%)$, difficulty in availing loans $(78.00 \%)$ and insufficiency of the money sent by the man to run the household affairs (77.00\%). 
Table.1 Problems faced by women in the absence of men

\begin{tabular}{|c|c|c|c|}
\hline $\begin{array}{l}\text { Sl. } \\
\text { No. }\end{array}$ & Problems & $\begin{array}{c}\text { Frequenc } \\
\mathbf{y}\end{array}$ & Percentage \\
\hline A & \multicolumn{3}{|l|}{ Socio-personal problems } \\
\hline 1 & Difficulty in making decision & 187 & 93.50 \\
\hline 2 & Lack of confidence & 123 & 61.50 \\
\hline 3 & Increased work burden & 200 & 100 \\
\hline 4 & Lack of social security & 147 & 73.50 \\
\hline 5 & $\begin{array}{l}\text { Inability to visit parent's house or relatives due to lack } \\
\text { of time }\end{array}$ & 78 & 39.00 \\
\hline 6 & Not able to maintain & 101 & 50.50 \\
\hline B & \multicolumn{3}{|l|}{ Economic problems } \\
\hline 1 & Difficulty in availing loans & 156 & 78.00 \\
\hline 2 & Irregular remittance & 200 & 100 \\
\hline 3 & Harassment by local money lenders & 184 & 92.00 \\
\hline 4 & Less wages than men & 178 & 89.00 \\
\hline 5 & Other family members are not co-operative & 102 & 51.00 \\
\hline 6 & Remittance sent is insufficient to run household affairs & 154 & 77.00 \\
\hline C & \multicolumn{3}{|l|}{$\begin{array}{l}\text { Psychological problems } \\
\end{array}$} \\
\hline 1 & $\begin{array}{c}\text { Fear regarding social security,domestic violence } \\
\text { \&abusive } \\
\text { behavior etc. }\end{array}$ & 124 & 62.00 \\
\hline 2 & Feeling of anxiety/ depression & 98 & 49.00 \\
\hline 3 & Feeling of loneliness & 174 & 87.00 \\
\hline 4 & Emotional stress & 120 & 60.00 \\
\hline 5 & Eve teasing & 147 & 73.50 \\
\hline 6 & Feeling insecure due to absence of husbands & 136 & 68.00 \\
\hline 7 & Sleep disturbances & 123 & 61.50 \\
\hline $\mathbf{E}$ & \multicolumn{3}{|c|}{ Common reproductive health problems } \\
\hline 1 & No sexual satisfaction & 31 & 15.50 \\
\hline 2 & Delayed conception & 61 & 30.50 \\
\hline 3 & Inability to visit gynecologists & 91 & 45.50 \\
\hline $\mathbf{F}$ & \multicolumn{3}{|l|}{$\begin{array}{l}\text { Agricultural problems } \\
\end{array}$} \\
\hline 4 & Lack of ownership of land & 93 & 95.87 \\
\hline 5 & Lack of mobility to procure inputs & 74 & 76.28 \\
\hline 6 & Lack of knowledge of intensive farming & 65 & 67.01 \\
\hline 7 & In ability to identify pest $\&$ diseases & 36 & 37.11 \\
\hline 8 & Non availability of female extension worker & 87 & 89.69 \\
\hline
\end{tabular}




\section{Psychological problems}

Psychological problems refer to the lack of emotional wellbeing of women. Common psychological problems experienced by the migrant wives include depression, anxiety, stress, insomnia, loneliness, irritability and fatigue. In relation to the rural context, living conditions associated with poverty, stressful events, limited social and economic resources and other demographic disadvantages pose a greater risk for psychological problems.

Majority of the women expressed feeling of loneliness because husband is away from home. Often men do not find time to have long conversations with their wives and so the woman feels that she cannot discuss certain personal problems making her feel lonely.

With the migration of the husband, household workload of the woman goes up substantially. Men used to help wife in various activities like taking responsibilities of children, farming activities, caring for the livestock and like going to the market, participating in social functions etc. After migration wife is deprived of the companionship emotional security that a husband provides, any help \& protection she may have had from her husband is no longer available to her the woman is also anxious about the safety of her husband. With all these reasons migrant wives undergo psychological problems like feeling insecure due to absence of husbands $(68.00 \%)$, fear regarding social security, domestic violence and abusive behaviour by other men and elders in the family $(62.00 \%)$, sleep disturbance $(61.50 \%)$, emotional stress $(60.00 \%)$, not wanting to participate alone in social functions (54.50\%) and feeling of anxiety or depression (49.00\%).

\section{Reproductive health problems}

Reproductive health addresses the reproductive processes, functions and system at all stages of life. Reproductive health implies that people are able to have a responsible, satisfying and safer sexual life.

The reproductive problem expressed were unable to visit gynaecologists (45.50\%), delayed conception $(30.50 \%)$ and less sexual satisfaction $(15.50 \%)$

\section{Agricultural problems}

Women in rural areas perform most of the farming activities from sowing to harvesting, yet their access to resources is less than their male counter parts. In spite their dominance of the labour force women in rural area still face extreme disadvantages in terms of pay, land rights and representation. Furthermore, their lack of empowerment often results in negative externalities such as lower education level prevent women from participating in more skilled labour sectors.

Large majority (95.87 \%) of migrant wives expressed that they had no ownership of land. Traditionally men have been owners of land and so women are unable to access land and other resources. It is said that the women world over produce 80.00 per cent of crops and own about one per cent of land. And in most cases this one per cent own small land holdings and less fertile lands. About 90.00 per cent of migrant wives expressed lack of female no female extension workers to inform them about agricultural schemes and programme. Other problems mentioned were some lack of mobility to procure inputs (76.28 $\%$ ), lack of knowledge about seed selection and inability to identify pest and diseases. Women tend to face greater challenges when it comes to making purchases as they are less experienced with purchasing of seeds, fertilizers and pesticides from inputs dealers, agriculture departments and agricultural universities without assistance and support of the husband. 
For women who are coping with long term and frequent male absence it is imperative for local community structures as well as organisations to keep vigil on their security and rights which run the risk of easy manipulation and violation. It will be useful to create a drop in centre that women can approach in case of grievances and that swings into urgent action upon being alerted. Such a centre will benefit from recognition by the panchayats or local authorities. Practical support that makes it easier for women to participate in social and economic fronts should necessarily be provided by the organisations working in this region.

\section{References}

Gupta, N., 2014, To study how MSME can contribute to overcome the problem of rural migration and helps in its development, Intl. J. of multidisciplinary Res. in Soc. and
Mngt. Sci., 2(2): 33-39.

MinaxiPathak 2000, Managerial problems and coping strategies in female headed households, Asian Journal of Home Science, 3 (2): 216-220.

Omprakash, P. Sharma, M. L., Paraye, P. M. and Soni, V. K., 2009, Migration effect of agricultural labourers on agricultural activities, Ind. Res. J. Ext. Edu., 9(3): 18-22.

Paris, T., Singh, A., Luis, J. and Hossain, M., 2005, Labour outmigration, livelihood of rice farming households and women left behind: a case study in Eastern Uttar Pradesh. Economic and Political Weekly: 2522-2529.

Paris, T., Singh, A., Luis, J. and Hossain, M., 2005, Labour outmigration, livelihood of rice farming households and women left behind: a case study in Eastern Uttar Pradesh. Economic and Political Weekly: 2522-2529.

\section{How to cite this article:}

Veena Chandawari and Shobha Nagnur. 2019. Problems Faced by Women in Male out Migrant Households. Int.J.Curr.Microbiol.App.Sci. 8(11): 1141-1146.

doi: https://doi.org/10.20546/ijcmas.2019.811.134 